\title{
Desheredamiento y desafuero, o la pretendida justificación de una revuelta nobiliaria
}

\author{
Isabel Aufonso
}

Instituto de Historia, CSIC

SIREM, GDR 2378, GNRS

Outrage publié avec le concours du SIREM (GDR 2378, CNRS)

et de l'ILCEA (UPRES-EA 613, Université Stendhal-Grenoble 3)

Les Cahiers de linguistique et de civilisation hispaniques médiévales continuent et remplacent les ex-Cahiers de linguistique hispanique médiévale, à partir du $\mathrm{n}^{\circ} 24$ (2001).

\section{ISSN 0396-9045}

ISBN 2-84788-012-7

\section{(C) ENS Éditions, 2002}

École normale supérieure Lettres et sciences humaines

15, parvis René Descartes

BP 7000,69342 Lyon cedex 07

tél. $0437376022-$ fax 0437376096

\section{RÉSUMÉ}

Cette étude porte sur le récit très singulier que fait la Chronique d'Alphonse $\mathrm{X}$ de la révolte nobiliaire à laquelle dut faire face le monarque au début des années 1270. L'on y examine les voies et les formes de la communication politique, faites d'affrontement et de négociation, en tant qu'elles constituent des moments de la lutte politique. L'on y analyse également les ressources culturelles dont disposaient les agents sociaux pour légitimer leur comportement, y compris les moyens employés par le chroniqueur pour construire la signification du récit qu'il transmet.

\section{RESUMEN}

En este trabajo, a partir del muy singular relato que se contiene en la Crónica de Alfonso $X$ sobre la revuelta nobiliaria que en los primeros años 70 del siglo xuI hubo de enfrentar este monarca, se indaga y reflexiona sobre las vías y formas de comunicación política, que son también de disputa y negociación, como momentos de la lucha politica, y se analizan los diversos recursos culturales que tenian los agentes sociales para legitimar su comportamiento, incluidos los medios utilizados por el cronista para construir el significado del relato transmitido.

\footnotetext{
CLCHM, n²5, 2002, P. $99^{-129}$
} 


\begin{abstract}
No es frecuente que las rebeliones protagonizadas por los grandes contra embargo, contiene uno de los relatostadas. La Crónica de Alfonso $X$, sin cemos sobre la revuelta que en los primes extensos y detallados que conoenfrentar ese monarca. Dicho los primeros años 70 del siglo XII hubo de zos de 1272 el infante don Felipe describe el modo en que a comienprincipales linajes magnaticios : hermano del rey, y los jefes de los tres hombres, se alzaron contra Alfonso, Haro y Castro, junto a otros ricosimportante de peticiones, que pese $X$, al que presentaron una lista Cortes, no impidieron su exilio junto a serles concedidas y ratificadas en largas negociaciones se resolvió el conflicy de Granada. Sólo después de devolvió a los nobles al servicio real.

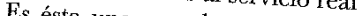

como « la primera rita que historiográficamente sigue considerándose codifica el Derecho y pretende elón de una pugna entre la monarquía, que que aspira a conservar o aumento de su autoridad, y la nobleza, citando a Suárez, dice asum ampliar el poder compartido » tal como de la Crónica'. Parece, pues, lugar coález Jiménez, el más reciente editor marco de la tradicional opos, lugar común interpretar este conflicto en el la primera a los intentosición nobleza/monarquía, como reacción de nes teóricas de un sistema corpalizadores de la segunda, a las formulaciodad de un rey y su código legrativo que la subordinaba a la superioriAlfonso $X$, su pensamiento, su obra jurínterpretación, la figura regia de lan en una confrontaciónto, su obra jurídica, su política regalista, se aísque sale vencido. Es cierto que la formu con los poderes tradicionales de la interpretación es muy variada, y que las conno argumentación, de esta atribuyen al desarrollo legal más que las connotaciones morales que se fuerzas feudales - muy obvias en la argopuesto por el rey frente a la califica al primero de « científico la argumentación de Ballesteros, que nariamente caduco $»^{2}-$ no aparecen al otro de «antediluviano y centeaparecen o están muy matizadas en trabajos
\end{abstract}

( posteriores ${ }^{3}$. Hay, sin embargo, un amplio acuerdo en que esta presión nobiliaria, en una coyuntura especialmente favorable para sus miembros, no a hacer fracasar los planes legislativos del monarca, a los que se les sigue atribuyendo la cualidad moral derivada del intento de someter a sigue atribuyendo nobles facinerosos $"^{4}$.

Desde otra perspectiva, sin duda, cabría haber aducido que esta rebeión, que habría aglutinado a miembros de la alta nobleza tradicionalmente divididos, es la primera oposición nobiliaria conocida en la que se documenta un programa de demandas presentado al rey, con el objetivo de limitar el poder creciente que éste quería atribuirse ${ }^{5}$. Sin embargo, en parte como resultado de la versión transmitida por la crónica y en parte por las propias concepciones de los historiadores acerca de cuál sea el mejor gobierno, apenas hay rastros de tal interpretación ${ }^{6}$.

No obstante, las trampas y problemas que entrañan estas argumentaciones dicotómicas, justifican evitar debates de este tipo, e inducen a adoptar enfoques diferentes para el estudio de este material cronístico que merece, ciertamente, un estudio detenido, pues entre otras cosas permite un análisis de los referentes normativos que informaban la práctica política de los grupos dominantes; explorar, por tanto, los diversos recursos que ofrecía una cultura legal - política si se quiere - a los agentes sociales para legitimar o justificar su comportamiento; abordar también el problema, más general, de la relación entre las normas y los procesos sociales en los cuales éstas se invocan y negocian, ratifican o transforman? ${ }^{7}$ Este es el análisis al que dedicaremos las páginas que siguen.

\section{TEXTOS Y GOMUNIGACIÓN}

Como es sabido, la Crónica de Alfonso $X$ fue redactada como continuación de la Estoria de España, durante el reinado de Alfonso XI, probablemente por su canciller, Fernán Sánchez de Valladolid, con una intencionalidad

3. J. E. O'GALLAGHAM, El rey Sabio. El reinado de Alfonso $X$ de Castilla, 1252-1284, Sevilla 1996; Fernando GÓMEZ REDONDO, Histona de la prosa nedieval castellana. 1. La creación del discurso brástico : el entramado contesaino; 2 . El desarrollo de lo géneros. La ficción caballeresca y el orden religiouso Madrid, 1998-1999: José Manuel PÉREZ-PRENDES, « Las leyes de Alfonso el Sabio », Revos, Madrida de Occidente, 43, 1984, p. 67-84.

4. El calificativo es de José Manuel PÉREZ-PRENDES, art. cit., p. 81.

5. Asi es, por ejemplo, como se interpreta la rebelión de los barones en 1215 en Inglaterra. Para un resumen reciente de la misma en el contexto de otras rebeliones de las que se diferencia Robert BARTLETT, England under the Norman and Angevin Kings, 1075-1225, Oxford, 2000, P. 51-67.

6. Una muy reciente excepción es Simon R. DOUBLEDAY, The Lara famizy. Growen and nobility in medieval Sodin, Cambritge, 2001 , esp. p. 62.

7. John COMAROFF y Simon ROBERTS, Rules and processes : the culural logic of dispute in an 7. John COMAROFF y Sin
african context, Chicago, 1981 . 
y unos condicionamientos que no pueden ser dejados de lado. Historiar a mediados del siglo XIV la figura de Alfonso $X$, suponía enfrentarse a la contracictoria y, por ello, dificil tarea de conciliar la legitimación de una realeza fuerte capaz de contener las ambiciones de la nobleza, cuestión candente en tiempos de Alfonso XI, pero omnipresente en los del rey Sabio, con el reconocimiento de la necesidad de su apoyo para afianzar el propio poder regio; de justificar además la línea dinástica reinante que había surgido del enfrentamiento con el rey sobre el que el cronista tenía que escribir. De ahí, en mi opinión, deriva fundamentalmente, y en gran parte, el carácter poco homogéneo del conjunto de la primera de las tres crónicas reales que este canciller ha de redactar como soporte ideológico de la cuarta, dedicada a Alfonso XI, más que de la naturaleza del material con el que cuenta, que, no hemos de olvidar, al reproducirlo está asumiendo.

Es cierto, sin embargo, que dentro de ese conjunto heterógeneo de la crónica, destaca la sección dedicada a la revuelta por su coherencia en deslegitimar las demandas de los más altos nobles del reino, que contrasta con los datos de capítulos previos que introducían elementos que justificaban dicha oposición ${ }^{9}$. Y en correspondencia con lo anterior, que a la imagen de un rey generoso hasta la prodigalidad, más interesado en su fama personal que en el bien de su reino de la primera parte, se oponga en esta narración la imagen de un rey cuyos problemas se deben a las ambiciones de una alta nobleza insaciable. Merecerá la pena examinar de qué medios se sirve el cronista para lograr estos efectos, cuáles son los recursos retóricos utilizados, porque uno de los aspectos más llamativos de la narración es la forma en que las demandas nobiliarias, aún concedidas, son desautorizadas.

Giertamente, la cuestión sobre la naturaleza del material que pudo servir de base para la elaboración de la Crónica, es de gran importancia.

8. Fernando GÓMEZ REDONDO, «De la crónica general a la real », en La historia alfonsí : el models y sis destinos (riglos XII-XV) (estudios reunidos e introducidos por Georges MARTN), Madrid, 2000, p. 11-112, trabajo que sintetiza en id., Historia de la prosa..., p. 965-968 y 97I-976; y Manuel CALDERÓN CALDERÓN, «la imagen del rey en la Crónica de Alfonso X », Boletin de la Real Academia de la historia, 197 (2), 2000, p. 255-266.

9. El más importante, sin duda, es el referido al tributo de Portugal (cap. XIX), que permite al cronista componer, recurriendo a un episoctio ficticio, do claros tonos épicos, pues en él resuenan ecos del Poema de Fernán González por cntonces en pleno auge de popularidad, un antecedentc idóneo para la inserción del relato sobre la rebelión, proporcionando a ésta un detonante justificador del que carecía : que el rey no acepte el consejo nobiliario atento a conservar el patrimonio de la corona, y anteponga su propios intereses a los del reino. Este pasaje cs esencial en el hilo argumental de la crónica pues al aportar cierta base de legitimidad al descontento de los nobies contrarresta hasta cierto punto la deslegitimación gue cste recibe en capítulos que siguen sobre la revueita, en los que es la imagen del buen hacer del rey la que se contrapone al mal hacer de aquellos.
Los dos análisis más recientes que conozco que tratan de reconstruir el proceso de formación de esta crónica y descifrar sus componentes textuales, aunque aparentemente muy similares, difieren, en mi opinión, en aspectos sustanciales. Mientras que Fernando Gómez Redondo acentúa el carácter ideológico de la labor del cronista y trata de entenderlo con relación al contexto desde el que escribe, considerando que son estos factores los que explican los errores cronológicos y factuales que se han advertido en la crónica ${ }^{10}$; Manuel González Jiménez, más preocupado por averiguar la adecuación entre relato cronístico e información diplomática, atribuye esos desajustes a ignorancia de los hechos relatados, y sólo de la última parte afirma su carácter partidista ${ }^{11}$. Ambos autores, no obstante, parecen estar de acuerdo en el carácter documental de gran parte del material que se incorpora especialmente en su sección segunda, en la que me voy a centrar.

La singular información de esta sección sobre la revuelta, que ocupa casi la mitad de toda la crónica - un bloque de treinta y ocho capítulos (XX a LVII) de los setenta y ocho que la componen -, ha sido resaltada por González Jiménez, debido a la minuciosidad con que se detalla todo el proceso, y a los numerosos documentos que supuestamente incorpora ${ }^{12}$. Considera este autor que esta sección, que le parece la más antigua y coherente, derivaría de la utilización por el cronista de un escrito que supone redactado en la misma corte de Alfonso X, en el contexto de la rebelión de su hijo el infante don Sancho, para facilitarle un relato de la revuelta anterior en la que habían participado muchos de los ahora apoyaban al infante. La labor de Sánchez de Valladolid, en esta parte, se habría limitado a adaptar a la forma de crónica y a fragmentar en capítulos un relato que supone continuo, además de a incluir esas fórmulas que sirven para anunciar al final de cada capítulo el contenido del siguiente. En su opinión, por tanto, esta sección « reproduce casi al pie de la letra el relato de época alfonsí de la revuelta nobiliaria de 1272-1273", y piensa que deberíamos estar agradecidos al cronista del XIV por no intentar resumirlo, pues « de esta forma ha llegado hasta nosotros una serie de documentos - nada menos que 57 , y algunos de ellos enteros - * que de otro modo habrían desaparecido. Incluye González Jiménez a continuación la lista de los que, en su opinión, se transcriben literalmente o en extracto ${ }^{13}$. Por su parte, Gómez Redondo parece más inclinado a considerar que fue el propio cronista del XIV, por su condición de canci-

10. Sobre errores cronológicos debidos a propósitos concretos y no a desconocimiento, Historia da la prosa, p. 1280.

11. Crónica, Introducción, p. ix-kxiii.

12. Ibid, $\mathrm{p}$ xyii- $\mathrm{xx}, \mathrm{y}$ especialmente $\mathrm{xxxi}-\mathrm{x} x \mathrm{x} v \mathrm{i}$.

13. Ibid., p. xxxiti-xxxvi. 
ller regio, el que utilizando numerosos datos de la cámara real habría. redactado este relato « puramente documental» de los desórdenes que afectan al reino cuando Alfonso X no logra dominar a la nobleza rebelde, en su propósito de contrastar el modelo de un rey débil como el de este monarca a la contrafigura del Justiciero ${ }^{14}$.

Aunque mi intención no va dirigida a un análisis textual cómo el realizado por estos dos filólogos, sus interpretaciones sobre la naturaleza del material con el que voy a trabajar resultan fundamentales a la hora de entender cuál es y cómo se construye el discurso político transmitido. Es mas, dado que aparece como un hecho asumido que uno de los rasgos de esta crónica es el gran número de documentos que se incluyen y dado el significado o valoración, es decir, la autoridad, también asumida que suele concederse a este hecho, me atreveré a discutir estos argumentos en la páginas que siguen.

La estructura narrativa de la sección que contiene el relato de la revuelta es la siguiente :

1 - Comienza con la descripción de los pactos encubiertos que sus protagonistas hacen entre ellos para oponerse al rey y de las estrategias que planean y ponen en práctica para que no se descubran sus propósitos con el fin de ganar tiempo para reunir apoyos dentro y fuera del reino (cap. $\mathrm{XX}-\mathrm{XXI}$ ),

2- A continuación se muestra la reacción regia, primero ante los rumores que le llegan acerca de la trama, después ante el descubrimiento de su certeza (cap. XXI-XXII).

3- Los ricoshombres presentan al rey sus demandas, que les son concedidas en Lerma y ratificadas en las Cortes de Burgos (cap. XXIII-XXVI).

4- Reacción regia ante la inesperada ruptura y exilio nobiliario posterior a dichas concesiones (cap. Xxvm-Xxxvm).

5- Exilio en Granada. Intervención creciente de mediadores, como resultado de las estrategias de fuerza y acercamiento de las partes, en el proceso de negociación emprendido para lograr una avenencia que permita la vuelta al servicio regio de los nobles exiliados (cap. XXXIX-LIV).

6- Resolución acordada, avenencia final, en un contexto muy condicionado por los objetivos opuestos de las partes (cap. LV-LVII).

Mi análisis se va a centrar, sobre todo, en el punto cuarto de los arriba señalados, cuando después de enumerar las demandas que los ricoshombres hacen al rey, se describe la reacción de éste ante su partida del reino, a pesar de la respuesta positiva que ha dado a las mismas. Es en esta parte donde precisamente, a través de un estilo supuestamente epistolar, el rey

14. Historia de la prosa, p. 972 y 975 . reduce el conflicto a un debate verbal sobre el contenido de lo que sea desheredamiento y desafuero. Para su mejor comprensión es preciso, sin embargo, aludir aunque sea brevemente a la descripción del proceso previo.

Es un proceso largo, contado con sumo detalle, en el que los nobles rebeldes ${ }^{15}$ desde el comienzo y durante todas las negociaciones, son presentados con tintes negativos, reuniéndose a espaldas del rey, cuando este ha partido para Murcia, tramando acuerdos contra él

\begin{abstract}
- juntáronse todos en Lerma e fizieron pleyto e postura de se ayudar todos e - juntaronse todos en Lerma e fizieron pleyto e postura de se ayudar todos gase et cumpliese las cosas quel querían demandar (p. 60)-
\end{abstract}

y encubriendo sus verdaderas intenciones con muestras de estar sirviéndole lealmente, mientras buscan apoyos para su causa. Esia forma de contrastar las actitudes y comportamientos opuestos de las partes en conflicto tiene una clara dimensión normativa, pues es el medio de que se sirve el redactor para conseguir que la valoración de los personajes aparezca como objetiva, conforme a valores implícitos compartidos.

Es de advertir la importancia inusitada que en esta situación cobra el rumor político, erigiéndose en uno de los elementos fundamentales en el desarrollo de la acción narrada ${ }^{16}$. El rey haciéndose eco de los rumores que le llegaban, de las cosas que comunalmente oya relativas a la conspiración nobiliaria, envía a sus mandaderos para que intenten averiguar indirectamente lo que está ocurriendo, y a través de sus mensajes transmitan a los principales de estos ricoshombres la incredulidad que tales noticias le producen, y la gravedad de que fueran ciertas. Es de notar también, el papel que en este proceso se otorga a un intenso intercambio de mensajes orales y escritos, la importancia, por ello, que en el mismo adquieren los mensajeros, cuya función negociadora es clara en muchos casos ${ }^{17}$. De este modo, la información que el lector-oyente recibe a través de estas formas narrativas le incluye y le hace participar del clima de tensión que se va comunicando, preparándole para compartir las reacciones emocionales de los personajes de la historia que se está narrando. No le falta

15. Este grupo de ricos hombres encabezado por el infante don Felipe, hermano del rey, y don 15. Este grupo de ricos homo Diaz de Haro, integraba igualmente a los principales de otras granNuño de Lara y don Lope Diaz de Haro, integraba igualmente a los principales de otras guan
des familias : don Esteban Fernández, don Fernando Ruiz de Gastro, don Simón Ruiz de los Gameros, don Juan Nuñez y don Alvar Díaz, que son los que aparecen nombrados en diferentes pasajes de la crónica. Sobre la identidad de los mismos y, en general, para notas explicativas de los hechos relatados ver el cuidado aparato crítico de la edición de la Crímica por M. González Jiménez.

16. « [...] de tantas partes le enbiauan apercebir diziendo que aquel ayuntamiento eran grand 16. « $[\ldots]$ de tantas partes le enbiauan aperçebir diziendo que aquel ay cartas e su mandadero $[\ldots]$.. (p. 62)
su danno e grand su deseruiçio que enbió luego sus cartas 17. El rey les manda que « fablasen con ellos de su parte e fiziesen quanto pudiesen por los quitar de aquel alboroço» (p. 85). 
razón al editor de la crónica al señalar el carácter periodístico de este relato ${ }^{18}$, aunque habría que pensar también en géneros literarios más cercanos que a través de ese tipo de recursos logran movilizar esquemas de percepción y valoración de su público. Particularmente elocuente es el mensaje enviado a don Nuño, en el que se observa como la incredulidad que se atribuye al rey, va referida a las expectativas que se derivan del comportamiento que se piensa adecuado. En ese sentido, cabe retener el carácter normativo de estas expresiones :

et porque tenía que ningund omne non deuía fazer más por guardar el fecho del rey que aquel don Nunno, que era marauillado desto que le dezían, et tanto semejaua syn razón, que lo non podía creer ${ }^{19} \ldots$

Carácter normativo igualmente revisten las respuestas que manda dar a cada uno de los motivos que adivina pueden estar detrás de este alboroco. Si era un intento de

poner miedo al rey, que sopiese que a grand tuerto e gran soberuia non dcue onbre auer miedo, ante se deue esforçar e pararse a ello.

\section{Si de lo que se trataba era de}

aver dél más bien de quanto auía, que siruiéndolo podríe ganar más ayna.

$Y$ si lo hizo

por fazer plazer a alguno otro del regno, que bien sabía él que de omne del mundo non resçebería tanto bien nin tanta ayuda commo del rey.

Carácter también moral, y desde luego político, al añadir para terminar que

por ninguna destas razones nin por otra non deuiera fazer tal yerro contra el rey,

\section{y por ello, que}

le rogaua como amigo e le mandaua commo a vasallo que sosegase el coraçón en lo seruir, asy como era tenudo de lo fazer.

La descalificación de las pretensiones nobiliarias, con la consiguiente construcción positiva de la figura del monarca, no siempre la hace cronista por estos medios indirectos, en algún caso interviene directamente, como al descubrir las verdaderas intenciones de don Nuño, detrás de la indicación que hace al rey de la conveniencia de que mandase recaudar otro servicio más en Castilla y en las Extremaduras para tranquilizar a algunos de los concejos que andauan despagados. El cronista nos explica que

18. $C A X, \mathrm{p} . \mathrm{xxxi}$.

19. Crórica, p. $63-64$ esto dezía él por dos cosas : lo vno por lo poner en enemistad con los de la tierra e lo otro porque ouiesen ellos dinero con que pudiesen fazer lo que tenían acordado (p. 65).

Es en este clima, de reiteración sobre la doblez de los rebeldes, quienes por un lado envian decir al rey que creyese que en ningún tiempo nunca le sinuier [an] de mejor mente que estonce, y por otro, se dedican a hacer muy gran danno a la tierra, en el que continua la narración, mostrando como el rey, pese avisos en contrario, accede a la recaudación de aquellos dineros, confiando en el servicio prometido que deseaba utilizar para su ida al imperio, pero también para mantener la defensa de la frontera frente a los moros de Granada. La negativa de los rebeldes a prestar ese servicio, junto a la demanda que le hacen de que acuda a Castilla para oír algunas cosas quel tenían que decir, la recibe Alfonso X en el mismo momento en que descubre la certeza de su complot a través de unas cartas arábigas que le son interceptadas al escudero de don Nuño que las llevaba; en ellas el rey de Granada ofrecía a cada uno de estos ricoshombres toda la ayuda que necesitasen en la lucha que tenían planteada ${ }^{20}$. Es entonces también, cuando el propio hijo de don Nuño le apercibe de los pactos que quieren poner con el rey de Navarra. Información que aprovecha el rey para advertirles, a través de sus enviados, de las implicaciones de tal pacto, invocando para ello lo que, sin duda, hemos de ver como una moralidad política compartida :

Que dixiesen de su parte... cómmo el rey de Nauarra era su enemigo e de todo el reyno e con tal omne non deuían poner pleyto nin postura contra su sennor natural seyendo ellos sus vasallos e teniendo dél las rentas de su tierra e dándoles él sus dineros, demás auiendo él con ellos buenos debdos asy como ellos saben, et que les rogaua que lo non quisyesen fazer (p. 75).

Pero el mensaje esta vez, como volverá a hacer posteriormente, también va dirigido a los vasallos de los rebeldes:

Otrosy enbió dezir e afrontar a los caualieros sus vasallos e a todos los otros que eran con ellos que catasen lo que fazian en aquel fecho; que bien entendían que era contra la lealtad a que eran tenudos e los deuían guardar (p. 75).

La respuesta que envían los ricoshombres niega una vez más que hubiera tales posturas, apelando igualmente, sin nombrarlo, a un código común que rige sus relaciones, aludiendo a las formas acostumbradas de ruptura vasallática :

E dixo al rey que bien sabía cómmo don Nunno auía posturas con él, que don

20. Crónica, p. 72-75. De las ocho cartas que se dicen interceptadas, sólo cuatro se presentan como transcritas, del resto solo se alude a un resumen de ellas. Tal vez es lo que quiere indicar González Jiménez, pese a incluirlas todas en su lista documental. 
Nunno nunca pusiese postura con christianos nin con moros que ante non gelo fiziese saber, et fasta entonçe que lo guardara,

aunque por primera vez le hace saber que de alli adelante que lo [non] quería fazer (p. 75). Es de advertir, como con esta reiterada negación de las acciones que se les atribuyen, los nobles afirman el comportamiento que ellos también entienden como debido y apropiado ${ }^{21}$. Don Nuño claramente se perfila como el protagonista indiscutible de este complot contra el rey a quien sigue atrayendo hacia Castilla mandándole decir que

Sy lo fiziese, que vería que nunca vasallo mejor seruiçio nin consejo dio a su sennor (p. 75).

y que de este modo

se tirarian todos los bollyçios e males que andauan en la tierra.

La promesa que recibe el rey de que saldrán a su encuentro para acogelle commo a su rey e su sennor natural (p. 76) forma parte de todo un preámbulo, que precede a la reunión donde le presentaran sus demandas, que, dirigido a enfatizar la violencia con la que actúan, sirve de nuevo para contrastar con la realidad con que le reciben, pues según el parecer que se atribuye al propio rey llegan a él

con muy grandes gentes de cauallo, e uenían todos armados e con gran asonada, no commo omnes que van a su sennor mas commo aquéllos que van a buscar sus encmigos, aunque continúen prometiéndol muchos seruiçios (p. 77).

Así, mediante la utilización de estos recursos retóricos, vemos cómo las demandas nobiliarias, aún concedidas, serán desautorizadas.

En el proceso de negociación que se inicia entonces, ya presentes las partes en la misma zona castellana de Burgos, interesa atender a lugares y formas, pues son elementos que utiliza el redactor para deslegitimar las pretensiones de estos magnates, de modo que las exigencias respecto al lugar del encuentro, la negativa a entrar en el recinto urbano por el recelo, que se nos dice infundado, a una posible actuación regia hostil y represora, que no parece sino proyectar la violencia propia, hacen fracasar los intentos de lograr un acuerdo por parte del rey y se impone la postura de fuerza de los rebeldes. Logran éstos que la respuesta a sus demandas tenga lugar en la glera de Burgos, un espacio en el exterior de la urbe

21. En este negar lo que hacen, afirmando lo que no hacen, hay que notar que uno de los modos por los que los nobles pretenden asegurar al rey su lealtad es fundarncntalmente apclando a su juicio para resolver disputas (p. 61). Ilustra que conocen bien el significado que tal acción ticne, pues, aún siendo una estrategia, supone accptar su autoridad, reconocer su poder. que se presenta así fuera del control regio. Fn ella, el rey contesta punto por punto a cada una de las peticiones presentadas ${ }^{22}$ :

- exención de los hidalgos del régimen foral concedido por el rey a algunas villas;

- aceptación del nombramiento de alcaldes castellanos en su corte para juzgarlos;

- comprensión hacia los problemas que les podían crear los prohijamientos o profiliaciones a favor de la familia regia, pero imposibilidad de prohibirlos por ser de fuero y costumbre;

- aceptación de las cuantias y formas de recaudar los servicios que le demandan;

- exención a los hidalgos de Burgos del pecho de alcabala;

- promesa de vigilar el cumplimiento de las obligaciones de merinos y cogedores y de hacer enmendar los daños que pudieran haber cometido;

- remisión del problema de las pueblas regias, de las que también dicen sentirse agraviados, a la decisión de caballeros y clérigos.

No hay más puntos en la lista presentada, pero el rey añade otra concesión de importancia crucial :

- que las querellas que pudieran tener de él serían juzgadas por sus iguales, no vinculados en ese momento a las partes, según el fuero antiguo usado por los otros reyes con los sus fijosdalgo.

Cada una de estas respuestas del monarca va acompañada de comentarios justificadores de los hechos que le han pedido sean rectificados, así por ejemplo cuando explica, en relación a las pueblas,

que él non mandara fazer puebla en heredat agena, e que faziéndolo él en lo suyo non desaforaua a ninguno $[\ldots]$;

o cuando aún accediendo a poner alcaldes castellanos aclara que él traya buenos alcaldes...; ; son expresiones que pretenden, en cierta medida, señalar que otorga pero no está conforme con las razones que asisten esas demandas. Pero donde más clara aparece esta argumentación justificatoria, es en una última razón regia que el narrador introduce al final de las respuestas concretas a cada demanda. En ella, a la reputación de prodigalidad que anteriormente le habían achacado diciendo que el rey enpobrescié la tierra dando algos a las gentes de otros reinos et otrosí por lo del Inperio, que recordemos - alude y enlaza con episodios previos a este relato de la revuelta ya señalados, el monarca responde con argumentos que justifican esos dos aspectos de su política, pues explica que si hacía donaciones a hombres de otras tierras

22. Crómica, p. 78-82. Aguna de estas peticiones son analizadas en detalle en el aréculo de Julio Escalona. 
que lo fazía por la honra de las gentes de sus regnos, e por esto que más amados e más presçiados eran los del su regno en todo el mundo que nunca fueran; y en lo relativo al fecho del Inperio, que por la honra de los sus regnos lo siguiera.

El propósito de esta autorrepresentación como buen rey que hace es explicito : invocar la ayuda de estos grandes en la elección imperial en la que también ellos se honrarían. Se trata, por tanto, de una legitimación política del imperio apelando al bien general, pero también particular de sus nobles. Más importante si cabe, es que el redactor ponga en boca del rey que sin el concurso de esta alta nobleza el bien que quería no podría realizarse, lo que, desde luego, puede entenderse como una estrategia retórica para concitar su apoyo, pero también, o precisamente por ello, la plasmación de un ideal político nobiliario :

les rogaua que non quisiesen que seyendo él buen rey fuese de mala ventura que quería fazer bien e non tenía con quien,

expresando a continuación un tipo de reciprocidad política que va a articular, como veremos, gran parte de los contenidos de la crónica, al menos esta parte :

ca bien sabían que nunca ouiera rey en esta [tierra] que tanto bien e tanta merçet les fiziese commo les él auia fecho, nin fueron nunca tan ricos nin tan abondados nin ouieron tantos cauallos nin tantas armas [commo] en su tiempo (p. 83)

Don Nuño es el que, de nuevo en nombre de todos, comunica la satisfacción general por las palabras del rey y el acuerdo de aceptar su respuesta y ponerse a su servicio :

que eran muy pagados con lo que les dizié e que por aquello sennaladamente eran tenudos de le seruir doquier que les él mandase,

aunque le pedian por merced que mandase ayuntar Cortes e que aquellas cosas que gelas dixese por Cortes (p. 84). De este modo, la convocatoria de una asamblea de este tipo para unos meses después en la misma ciudad de Burgos, donde pública y ritualmente se había de ratificar tal solución, parece que iba a cerrar de forma pacifica y sorprendentemente fácil estas duras negociaciones políticas. Sin embargo, el panorama que a continuación se presenta rompe con la lógica que ha presidido la narración anterior en un afán tal vez exagerado por deslegitimar la conducta nobiliaria, que el redactor consigue presentar como desmedida e irracional, con nuevas medidas de fuerza al exigir treguas para asistir a dichas Cortes alegando su temor a infantes y ricoshombres que eran con el rey ${ }^{23}$, y

23. Esta afirmación por sí sola debería servir para evitar la tentación de plantear el conficto como uno librado entre nobleza y monarquía, como dos entidades completamente diferenciadas. al añadir otras demandas a las anteriores, a las que el rey responde en el mismo tono conciliador anterior. Sus motivaciones se hacen ininteligibles, sobre todo la reacción final de no avenirse y abandonar las Cortes, y su cxilio posterior. De esta forma, se nos participa que

todos los que estauan y entendieron que él [rey] tenáa razón e derecho, e que don Felipe e aquellos ricos omnes fazían aquel alboroço con muy gran synrazón (p. 89).

En la contestación del monarca se han visto intentos de negociar más que de transigir a todo lo que piden. Se le representa intentando apaciguarles, de ahí los continuos mensajes de mediación que les envía, pero insistiendo, como ya hemos señalado, en la obligación de una bien reconocida reciprocidad politica :

les rogaua, pues él queria guardar sus fueros e derechos, qque guardasen ellos a él su sennorío e su derecho en todas las cosas (p. 90).

En el relato la imagen moral del rey, que no su poder, sale por ello fortalecida de estas Cortes, en las que hubo de hacer frente también a las demandas - oportunistas en versión del cronista - de los obispos, al presentarlo librando con los miembros de la asamblea lo que entendió que era pro de su regno.

\section{Desheredamiento y desafuero}

El bloque de diez capítulos que sigue a continuación en los que se narra la reacción del rey ante la ruptura nobiliaria constituye, sin duda, una de las partes de la crónica que reviste mayor interés, al que no parece ajeno el hecho de que los mensajes que dirige a cada uno de los ricoshombres implicados, empezando por su hermano el infante don Felipe y dos colectivos a los vasallos de éstos, que inician y cierran el conjunto, parezcan transcribirse completos. El contenido y estilo de este bloque permite presentar la politica regia de modo personalizado, transmitir y profundizar en la imagen del buen rey en contraste con la de una alta nobleza malhechora. Si fuera cierto que esta parte fue redactada todavía en el reinado de Alfonso X, parece claro que es el balance de un rey quejoso ante la respuesta negativa a su buen hacer político, pero es evidente que este contenido podía ajustarse igualmente a otras coyunturas similares. Grande es el interés de este material y en él, como he adelantado, centraré en gran medida mi análisis.

Los que abandonan el reino, que son presentados siguiendo el ritual de « despedida » caballeresco, aunque no el comportamiento, pues no respetan las treguas concedidas y en su marcha agravian la tierra con malfetrías, reciben muy pronto mandaderos de parte del rey que les 
transmiten su mensaje. El supuesto carácter de documentos oficiales que se ha atribuido a estos textos, de « cartas regias » que se copian e integran en el relato, parecería haberles otorgado un estatuto de verdad incuestionable, una autoridad distinta a la de otra información. Sin embargo, y a pesar de lo discutible que es tal distinción respecto a la credibilidad que uno y otro material merece, hay que precisar que lo que se presenta en estos capítulos de la crónica como transcrito literalmente no son cartas regias como se ha venido afirmando, sino los mensajes que de parte del rey transmiten sus mensajeros ${ }^{24}$, acreditados con cartas de creencia que los autorizaban para hablar en su nombre, para realizar la transmisión que éste les habían encargado ${ }^{25}$. No hay diferencia, en este sentido, con los mensajes cruzados que se han intercambiado antes sobre los que hemos visto se iba estructurando tanto la narración como, en cierta medida, la negociación entre los rebeldes y el rey. Sin embargo, en esta sección de la crónica, los mensajes cobran una importancia especial en gran parte por ese carácter de registros documentales que historiográficamente se les viene otorgando ${ }^{26}$

En mi opinión, hablar de cartas ha impedido profundizar en el análisis de las estructuras de oralidad de estos textos, en los esquemas de comunicación que recogen. Más importante por ello, que discutir si estos mensajes reproducían diplomas existentes en la cámara real que el redactor se hubiese limitado a reproducir, es atender a las diversas formas de comunicación política, y a su contenido, que éste nos presenta como posibles, es decir, verosímiles. En este sentido, no importa mucho si los consideramos meros recursos estilísticos, simples estrategias, para conseguir esos fines de verosimilitud de que quiere dotar al relato. El rey, es cierto, en ningún caso está presente, pero no es lo mismo leer el texto de una carta suya, que transmitir oralmente su mensaje. Lo comunicado, en este caso, es susceptible de ser elaborado y reinterpretado, también matizado, verbalmente por los encargados de transmitirlo, aunque les supon-

24. Esto queda muy claro en los títulos de cada capitulo : « De las razones que los mensajeros del rey dixeron a...; de parte del rey; o de don Alfonso. "

25. En mi opinión, la confusión a que me estoy refiriendo se debe precisamente a tomar las « cartas de creencia » de que se dota a los mensajeros para que su mensaje sea creído, con los mensajes que se les ordena trasmitir. El crédito que tales cartas otorgan a sus portadores no siempre es suficiente, como parece mostrar el ejemplo del mensajero judío enviado por don Nuño : «Et el rey non gelo quiso creer por quanto gelo dozía aquel judío. El luego otro día legó y un clérigo de la iglesia de Burgos que dezlan Pero Jaymes et traxo otra carta de creencia de don Nunno e díxol aquella mesma razón. " (p. 71)

26. Alude a ellos como « cartas justicieras », A. Ballesteros, op. cit., p. 594-615. De « riquísima colcción epistolar », habla F. Gómez Redondo, «De crónica general... ", p. 112; como " diplomatario politico », las menciona J. M. Pérez Prendes y M. Gónzalez Jiménez las incluye en su citada lista de documentos. gamos la mayor fidelidad en la reproducción de lo pedido por el emisor ${ }^{27}$. Pero sobre todo, responde a un estilo oral de comunicación, con todo el significado que esto tiene en relación a sus efectos retóricos, al proceso mismo de recepción.

Importa, por ello, atender al modo como se reciben estos mensajes regios. Dado que van dirigidos personalmente, excepto dos, a cada uno de los ricoshombres que encabezan la protesta, con detalles particulares de la relación que cada uno de ellos ha tenido con el monarca, podría pensarse que es de forma individual como los reciben, pues ciertamente lo que transmiten los mandaderos a cada magnate más parece responder a ese tipo de consideraciones que sólo se hacen privada e individualmente. Algunos datos, sin embargo, hacen pensar en una recepción colectiva, dadas las referencias resumidas a lo dicho a los otros: dezimos que vos... segunt que auemos dicho a cada uno de los otros, o a lo que el rey dijo a todos en uno e a cada uno por $s y^{28}$. En el primero de los mensajes, dirigido al colectivo, esto es indudable, y el reproche que a todos afecta por todos es escuchado. Reconocer este carácter público de la comunicación y el debate político al que se nos hace asistir, al formalizarse los mensajes como una réplica regia, muy personalizada, a las alegaciones de los nobles, es de gran importancia para entender las estrategias retóricas y referentes normativos que cada parte utiliza para « oficializar » sus propias demandas ${ }^{29}$. Es llamativo por ello, el gran espacio que el cronista, o redactor anónimo, da a los argumentos del rey, signo indudable de los efectos que pretende, pues es la versión del monarca sobre la situación la que de este modo prevalece. Para entender igualmente la importancia de distinguir entre formas diversas de comunicación bastará observar cómo se asume en toda la crónica que son diferentes las repercusiones prácticas de lo dicho en consejo que lo hablado en poridad, dos ámbitos que pese a su posible conexión, aparecen claramente diferenciados. Un ejemplo muy explícito de lo que exige una audiencia pública lo tenemos en el caso de don Juan Nuñez, el hijo del de Lara, que solo apartadamente declara que tiene razón el rey, al que pide perdón por haberse ido con su padre,

27. Ya sefialamos antes el papel destacado quc se hace jugar a estos mensajeros, nobles destacados en general, en la negociación política.

28. Expresión, esta última que ciertamente puede dar lugar a confusión, pero que interpreto 28. Expresión, esta úluma que ciertamente puede dar lugar a confusion, pero que interpreto como referida al contenido, general o particular, de los mensajes. La recepción colectiva de
éstos también puede deducirse de que todos juntos se retiren a delibcrar después de haberlos éstos también puede deducirse de que todos juntos se retiren a delibcrar después de haberlos
oído : «Después quel infante don Felipe e los ricos omnes e los caualleros ouieron aydo lo que les dixieron mandaderos del rey, apartáronse auer su acuerdo... " (p. 112)

29. Sobre las prácticas de oficializar, P. BOURDIEU, El sentido práctica, p. 184-185. J. COMAROFF y S. ROBERTS, op. cit, p. 70-106. De gran interés es la aplicación que bace White dc RO Lusignan », in : Histaire el Sociét? Mélianges offerts à Georges Duby, Aix-en-Provence, 1992, vol. ?, p. $147-157$. 
aunque en el mensaje que recibe lo que más resalta-reprocha el narradormensajero-rey, es la conducta « traidora » de este noble al que había confiado los secretos para negociar este asunto:

Et por esto se maravilla qué fue esto que vos enbiastes partir dél, sennaladamente porque en este fecho de los ricos omnes vos metié en su poridat e érades mandadero entre él e ellos, e de uos ternié quel verní seruiçio en esto e que non le faríedes deseruiçio con ellos (p. 109)

En esta misma línea, es preciso recordar también cómo los ricoshombres habían pedido al rey la confirmación de sus demandas en Cortes, con su doble sentido, institucional y en público. Igualmente, es de resaltar, la conciencia de que la honra y reputación, la fama de cada cual, se construye a través de lo que se dice comunalmente. Ahondar, por tanto, en estas vías y formas de comunicación, de circulación de información ${ }^{31}$, que lo son también de disputa y negociación como momentos de la lucha política, es fundamental para valorar el material que utilizamos, porque era bien sabido que las intenciones comunicativas influían - y siguen haciéndolo - en las técnicas narrativas

[...] dezir palabras en tal manera que onbre faga creer sus dichos a aquellos que los oyen $^{32}$

$\mathrm{Y}$ esto es, sin duda, lo que parece pretender Alfonso X, convencer a su audiencia $^{33}$, una audiencia que se reproduce a medida que lo hace su mensaje en el espacio, pero también en el tiempo, ya que incluso parece llegar hasta ahora mismo si observamos la implicación de algunos historiadores en aquel debate. Es cierto que el objetivo inmediato, aparente del monarca, es atraer de nuevo a estos nobles a su corte por la necesidad que había de ellos para la realización de su proyecto imperial. Pero más allá de este primer nivel, y es preciso sobrepasarlo, estos mensajes tienen un más amplio alcance político. Poseen la cualidad del estilo directo, como dirigidos a una asamblea en la que él mismo estuviera presente, y que fuera a juzgar sobre los hechos que se exponen, sobre la disputa que se debate. Las argumentaciones apelan así y refieren a unos principios normativos, a unos valores morales que los presentes entienden y comparten. Y esta forma de actuar y argumentar es, no lo olvidemos, una

30. Hay que recordar que efectivamente este hijo de don Nuño ha figurado como enviado regio en las negociaciones iniciales.

31. He tratado estos problemas acerca de la circulación de información y la construcción de reputación en «Venganza y Justicia en el Cantar de mio Gid» (cn prensa)

re quien se debe un espléndido análisis de la obra de este autor y del significado de su recepción quien se debe un espléndido análisis
er la corte castellana, en p. 863-890.

er la corte castellana, en p. $863-890$.
33. Toda la estructura de la crónica, según F. Gómez Redondo, va dirigida a estos propósitos, itid., p. 1267. característica de los modos de funcionar de la justicia medieval, una de las vías más comunes de resolución de conflictos. De ahí tal vez, la similaridad con los relatos que se encuentran en muchas fazañas, o que recuerde en cierta medida al tipo de narraciones ejemplares que se insertan en las crónicas, aunque sería necesario un estudio en esta línea más detenido del que podemos hacer ahora, que pudiera confirmar o rectificar esta hipótesis de trabajo que aquí vamos a manejar.

No parece baladí esta pretensión alfonsina de que sus razones sean convincentes, si pensamos en la contestación que está sufriendo su política. De ahí el interés de analizar el tipo de problemas que se discuten en este material y los argumentos que se utilizan para hacerlo, sobre todo teniendo en cuenta que las más formalizadas demandas hechas por los ricoshombres, de las que el cronista ha dado cuenta antes, no han merecido tamana presentación argumental y aparecen, como hemos visto, concedidas tal como las formulan con solo ligeras observaciones. Este estilo narrativo, no puede ser casual y sin duda, tal como señalábamos más arriba, tiene como objetivo producir unos efectos determinados en los lectores u oyentes del relato. Pero que esto sea así no implica que no trasluzca variaciones en los modos reales de comunicación dependiendo del foro donde vayan a hacerse ${ }^{34}$. Simplemente, un análisis contrastado de cómo la disputa es presentada en unos y otros contextos merecería la pena, como vía de acceso al significado de las distintas representaciones de los mismos sucesos en ámbitos y circunstancias diversos ${ }^{35}$, aunque no sea este el objetivo que ahora nos proponemos.

En estos mensajes, que son ciertamente piezas excepcionales - posiblemente desde más puntos de vista de los que se han señalado -, un rey sabio y letrado como Alfonso $\mathrm{X}$ no sólo reprocha al grupo de sus barones al que poco antes ha concedido en Cortes sus demandas, su mal comportamiento y acciones sino que lo hace apelando a un código moral y normativo que parecen compartir. Todos tienen una misma estructura narrativa, el rey comienza haciéndose hace eco de las razones que han dado los ricoshombres en su despedida para exiliarse del reino, y las desmiente con referencias a la historia de la relación particular que ha tenido con cada uno de ellos, ofreciendo además su versión del desarrollo del conflicto hasta el momento, de los hechos que hemos ido conociendo, aunque no del mismo modo, en los capítulos previos. Sabemos así los dos motivos que los nobles habían alegado para despedirse, que al

34. Maurice BLOCH, Political language and oratory in traditional socity, Londres y Nueva York, 1975.

35. Para un contraste de este tipo, ver Isabel ALFONSO y Cristina JULAR, « Ofia contra Frías o el pleito de los cien testigos: Una pesquisa en la Castilla del siglo xur ", Edad Media. Revista de historia, 3, 2000, p. $61-88$. 
ser repetidos al inicio de cada mensaje, como pretexto para el propio alegato regio cobran, por ello, protagonismo inusitado ${ }^{36}:$ deseredamiento $\mathrm{y}$ desafuero. Dos nociones en negativo, que parecen concentrar gran parte del pensamiento político nobiliario respecto al buen y justo gobierno que reclaman. Una remite a situaciones personales : su patrimonio en sentido amplio (deseredamiento que vos fazía, había alegado don Felipe; que porque vos tenía deseredado e non vos daua aquella tierra que solía tener vuestro padre e vuestro avuelo, había sido la justificación de don Lope); la otra refiere a una situación general : el reino y el derecho (e porque dezíades que el rey desaforó Castilla e Lén que vos partides dél, o expresiones similares). Dado que el monarca a través de sus enviados discute de forma particularizada el contenido de estos hechos que se le imputan, y a que en estos discursos es posible observar como ambas alegaciones se imbrican, podemos igualmente explorar alguna de las cuestiones que en este coloquio se plantean en relación a la existencia, o no, de concepciones políticas de la nobleza y de la monarquía, propias y diferenciadas.

Veamos, ¿ qué entienden los ricoshombres por desheredamiento, o mejor, cuándo y por qué causas dicen considerarse desheredados? ¿ qué tipo de bienes habian sido afectados por tal medida regia? El término desheredar parece referirse aquí a un patrimonio recibido por herencia del que habrían sido desposeídos o confiscados sin razón. Afirma, por tanto, al negar, el incumplimiento de uno de los deberes regios con tan grandes vasallos. Asi el infante don Felipe había alegado quel rey uos deseredaua, sennaladamente del infantadgo de tierra de León (p. 97), motivo utilizado igualmente por don Fernando Ruiz de Castro que porque él vos tenié deseredado del infantazgo de tierra de León, que uos partiedes dél (p. 106). Los dos magnates reciben la misma respuesta del rey, haciéndoles saber que esta heredad había sido entrada, es decir apropiada, sin su conocimiento, por mandato de su hijo Fernando, debido a la profiliación que en su favor había hecho a su muerte la reina doña Mencía de Portugal. En este caso, el problema parece estar relacionado con la frustración de las expectativas hereditarias que ambos tenían como parientes politicos de los Haro, familia a la que pertenecía doña Mencía, debido al mecanismo legal que facultaba para prohijar y, por ello, heredar a quien se quisicra. La supresión de este derecho, hemos de recordar, era una de las peticiones que los nobles habian incluido en su programa, aunque en éste se formulaba como agravio de carácter general :

E la oira razón for que se tenían por agrauiados era de los porfjamientos que el rey e sus fjos regebian de los ricos omnes e de los fjosdalgo, por que fincauan deseredados

36. Sobre los efectos de este estilo narrativo, ver S. WHITE, art. cit., p. 148. y recordar también como el rey les había respondido que

fuero era et costumbre de porfijar los omnes a quien quisiesen, et que en esto non podía él toller el derecho que sus fijos aúan (p. 78),

aunque él personalmente renunciase a ejercerlo. Es un asunto que muestra los problemas y tensiones, no nuevos sino recurrentes, que rodeaban la distribución y transmisión patrimonial en el interior de estos grupos sociales.

La alegación para despedirse de don Nuño se refería a que le habia tomado la tierra de concesión regia cuando estaba en su servicio, es decir, sin motivo : porque vos, seyendo en su seruiçio en Málaga, que tolliera la tierra que dél teníedes (p. 99). La réplica del rey, después de enumerar las incontables mercedes concedidas, es que

nunca vos tolló la tierra que dél tenédes, nunca vos lo tollió ante vos lo cresçió todavia tanto que nunca fue rico omne en Espanna que tanta tierra ouiese del rey o de sennor (p. 101).

En este caso es preciso señalar que no se habla de desheredar sino de toller, referido parece a concesiones, es decir, no a heredades sino a tenencias. Pero lo que se produce, en cualquier caso, es también una oposición entre el buen comportamiento del rey y el mal hacer nobiliario.

Don Lope Díaz ha justificado su despedida diciendo

que le tenía deseredado e non vos daua aquella tierra que solía tener vuestro padre e vuestro avuelo, que vos teníades por más desonrado avn que non de la heredad que vos dexara vuestro padre.

Claramente, por la respuesta transmitida en el mensaje regio, se puede suponer que sus argumentos debieron ser más detallados, pues menciona Orduña y Balmaseda como las heredades en concreto a que se refiere cuando alega desheredamiento. Esta vez el rey no niega el hecho, pero devuelve la responsabilidad de que así haya sido al mismo don Lope, dado que

fuero es de Castilla que si de la donaçión que el rey da, le fazen guerra e mal en la tierra, que la pueda tomar con fuero e con derecho.

Acciones éstas que con gran detalle denuncia ha cometido el de Haro desde esas posesiones, de tal forma que - le envía decir-

uos mesmo vos deseredastes et aquéllos que vos tenían en poder et en guarda, ca el rey non pudo escusar de fazer lo que era fuero e derecho (p. 104).

En este caso parece distinguirse, implícitamente, entre heredades propias y de donación regia; el hecho de que no se las denomine tenencias como a las de don Nuño, puede ser indicativo de tipos diversos de conce- 
siones; puede, tal vez, referirse a que fueron donadas iure hereditario, pese a lo cual parecen mantener un carácter diferente de aquellas del patrimonio familiar; aunque puede tratarse también de un tipo de concesión regia que conservando el carácter de tal, se asume ha de pasar de padres a hijos si no hay ningún problema.

Don Esteban Fernández por su parte tampoco habla de desheredamiento, pero igualmente alega razones personales que afectan tanto a su economía como a su capital político :

que porque aúa grant tiempo que uos non diera vuestros dineros e porque vos tenía a Aldonça Rodríguez vuestra esposa por fuerça,

hechos que el rey niega señalando las muchas mercedes que también le había concedido.

Al igual que don Nuño, la alegación para despedirse del rey de don Alvar Diaz ha sido que le tomara la tierra concedida sin motivo : non faziendo vos por qué. La respuesta que envía transmitir Alfonso X va en el mismo sentido, es la ruptura del pacto de servicio que conllevan las mercedes regias, ese deseruti en muy mal son e en muy mala manera que le reprocha, la causa de que haya perdido su tierra. Nuevamente, nos es dado observar que el argumento del monarca invoca una clara reciprocidad política que no se ha cumplido, pues en este caso

él auié sabor de uos fazer bien quando vos lo amásedes con seruiçio así commo deuédes, ante le prometiestes quel seruiríedes porque oviésedes su amor e su merçed.

Se trata, por tanto, de la repetida apelación a un orden moral, a la par que jurídico, de intercambio de amores y mercedes politicas por amores y servicios también políticos ${ }^{37}$.

Ciertamente, entre las obligaciones que se esperan y exigen del rey, y que éste en su discurso asume como elemento intrínseco a su poder y prestigio está la de heredar a sus vasallos, criarlos, casarlos y concederles dineros de las rentas regias ${ }^{38}$, mediar en sus conflictos, juzgar y castigar sus malfetrías... Los mensajes del monarca son en este sentido formidables fuentes de información, pues al describir sus relaciones con cada uno de los ricoshombres a los que se dirigen, enfatizan los vínculos personales tan particulares en los que se han concretado los favores y mercedes que

37. Sobre amor politico es de gran interés, Georges MARTIN, « Amour, une notion politique $»$ in: Histoires de l'Espagne médiévale. Hisloriographite, gesié, romancero, Paris : Klincksieck, 1997, que $\gg$ in: $H$ p. 169 - 206 .

38. Así afirma, al reprochar que se le acuse de desaforar Castilla y León, que « non lo faze nin es su voluntat de lo fazer, mas crió e cría en su casa muchos fijosdalgo e díbles casamientos e fizolos caualleros e heredólos e fizoles mucho bien, más que otro rey en Espanna fuese fasta en el su tiempo $\$$ (p. 104). cada uno ha recibido, los debdos particulares, por ello, también contraídos, que hacen todavía más condenable e injustificable su conducta, agravando los actos que han cometido.

Es en los mensajes a don Nuño de Lara y a don Lope Díaz de Haro, cabezas de las dos principales facciones nobiliarias - tradicionalmente enfrentadas pero actuando ahora en común - donde se pone mayor énfasis en la singularidad de los favores recibidos, y no sólo por su cuantía sino por el contexto y forma en que han sido concedidos. Así, la relación del rey con don Nuño se presenta como muy estrecha desde su niñez, pues se criaron juntos y cuando era infante le protegió, incluso contra los deseos de su padre, y también ayudó a los suyos, impidiendo la represión que el alzamiento y deservicio de éstos habría merecido. Le benefició igualmente contra la voluntad paterna, hasta conseguir que fuese aceptado en el círculo regio, le armó caballero y le organizó su casamiento ${ }^{39}$. No sólo eso, todavía siendo infante Alfonso le había apoyado, tanto en la contienda por un heredamiento con el padre de don Lope, su actual aliado, aún sabiendo que la demanda era ilegal, como en asonadas que hizo en Castilla ${ }^{40}$. Estos beneficios que otorgó a don Nuño - le recuerda - se incrementaron cuando empezó a reinar hasta tal punto, que el de Haro le pidió muchas veces merçed que lo non fiziese, ca todo lo que en vos fazía era desfallesçimiento dél. Los favores fueron tantos en rentas, tierras y oficios que don Diego abandonó el reino pues esto era muy grant honra para vos e muy grant quebranto para él, y nunca le pudo tener en su servicio, es más le deseruio... con todos aquellos quél entendió que querían mal al rey. Claramente se está aludiendo aquí a fenómenos de privanza y exclusión política como inhe-

39. «Et vos sabedes que del rey resçebistes mucha honra e mucha merçet, más que nunca 39. «Et vos sabedes que del rey resçebistes mucha hon en Espanna omne de la vuestra guisa de otro rey, ca, seyendo él ninno, criástesvos con reçibió en Espanna omne de la vuestra guisa de otro rey, ca, seyendo é ninno, criástesvos con
el, e seyendo él infante, quando començó a tener casa, por lo vuestro tomó en su casa e en la su merçet a Gonçalo Núnnez, vuestro hermano. E el rey don Fernando non vos queria fazer cauallero nin daruos tierra nin aúa voluntat de fazer [vos] bien, ante queria mal a vos e a todo vuestro linaje por quel conde don Fernando e el conde don Aluaro, vuestros tíos, et el cond don Gonçalo, vuestro padre, que era quando él començó a regnar, se le alçaron e le desiruieron mucho faziéndole grant guerra. Et el rey don Alfonso seyendo infarte, contra voluntad de

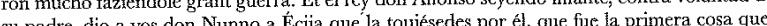
su padre, dio a vos don Nunno a Eçja que la rouia rey don Fernando le dio en el Andaluzía seyendo infante. Et la primera vez que el rey don Alfonso fue al regno de Murçia, scyendo infante, dióvos heredat. E después rogó e pidió al rey don Ferrando, su padre, que vos diese tierra et vos fiziese cauallero et vos diese en casamiento a donna Teresa Alfonso, su commana, nieta del rey de León. Et el rey don Ferrando, por ruego del rey don Alfonso su fijo, fizouos estas merçedes muy contra su voluntat. » (p. 99)

40. «Et después tomastes contienda con don Diego sobre eredamiento de la Montanna, et 10. «E desuer comno quier que sabia el la heredat fincó viestra pesando al rey su padre. En que tobo que conbusco de mancra que la heredat finco vin. Et después des vos fizo merçet más que en ninguna otra cosa. Et después desto, vos don Nunno ouicstes vuestras asonadas en Castiella et tantos amigos vos dio el rey don Alfonso en aquel ticmpo, scyendo
infante, que vos fincastes en vuestra honra. » 
rentes a la misma dinámica de poder, que el rey en su mensaje insiste en hacer presentes a don Nuño:

deuiedes entender quánto fizo el rey por vos en perder tal omne como don Diego por fazer a uos el mejor de su regno ${ }^{4}$

Es esta una dinámica que no debería ser olvidada a la hora de expliar los procesos de competición política interna en los que estos magnaes están inmersos, derivada de lo limitado de los recursos políticos y de las formas de acceso y asignación de los mismos. Hay que resaltar que, en este sentido, interesa menos la certeza de los datos a que se refieren los mensajes, que la certeza o verosimilitud de los procesos aludidos.

En esta misma línea, el rey en su mensaje a don Lope le recuerda oualmente aspectos importantes de la relación personal entre ellos cómo a la muerte de su padre le acogió en su casa a pesar del deservicio le armeros el mismo día de la boda de su hijo el infante don Fernando ${ }^{42}$. Pero, sobre todo, dia de la bodá de su disputa con don Nuño sobre Durango y Vizcaya, hasta el punto de ofender a éste; es decir, que la mayor merced que le hizo fue crearse enemigos por ayudarle ${ }^{43}$. Se comprueba cómo esta ayuda regia a don Lope es opuesta a la que tuvo con su padre frente a dos casos la reclamación de éste último Datos éstos que permiten advertir cómo estas difese diga fue con tuerto. Datos ćstos que perás a estrategias acordes a coyunrentes actuaciones parecen obedecer mas a estrategias acordes a coycicos o turas concretas diversas que a la oxperiencias de hostilidades y reconjurídicos abstractos, pues hablan de experienci 1. Se enumeran otras muchas mercedes, alguna incluso había puesto en entredicho el prestigio del monarca como la de conceder tierra a los hijos en vida del padre : "Lt en el vuestro tempo dio el rey tierra a vuestros fijos don Juan Núnnez e Nunno Gonçález, lo cual ante nunce fue fecho en tiempo de ningunt rcy que en vida del padre diese tierra a los fuem tantas que ron los del regno mucho que dezir (p. 100). Rn fin, la honra y las mo de Espanna » (p. 10 ) vos erades el más poderoso omne que sennor ouiesse e ras ho ha 42. "Don Lope Diaz, vos sabedes quantas merçedes vos fizo ca quaando muno don Dieso 2. «Dé viestro padre, commo quer que mucho honradamiente et fizo al infante don Fernando su fijo tomóvos en la su casa et tráxovos mucho hodas e dióvos mucha honra et muchos dineros que que vos fiziese cauallero en el dia de stis bodas

vos puso para de cada anno. $"$ (p. 102-103) 43. «E tanta merçet $e$ tanta ayuda vos fizo el rey en csto, que Viscaya, ca si el non vos la guardara, don Nunno ha del rey es ésta... Et por esto oulestes vos a Wizo él mucho bien e mucha honrà. descredado fiérades della. Et en esto e en otras cosas vos fizo el mu

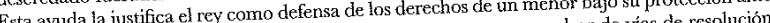
Esta ay da ju presentándose además como propulsor de vas de icsolución una medida de fie de confictos pacificas y ní vos demandasc commo devía et que taria de uos con estando en su poder. Et por esto ouiestes sentié que vos fiziese fuetça seyendo vos peqquenno e esado fuérades della. Et en esto e en otra vos a Viscaya, ca si él non vos la guatdara, desereda ciliaciones entre reyes y familias de la alta nobleza, de cómo herencias de enemistades se pueden mantenter o perdonar según convenga. Es aquí donde, en mi opinión, el cronista pudo verter su gran experiencia y saber políticos.

El desafuero, el otro gran motivo que aducen los ricoshombres como justificación para su ruptura y exilio, no es planteado como cuestión personal sino como una actuación que afecta al reino $\dot{i}$ Cuáles son los actos que los nobles consideran desafuero? ¿ Cuál es el fuero que invocan para definirlos como tales? ¿Alude el monarca a un fuero diferente? El vocablo fuero en los textos de la época es, sin duda, incluso en términos estrictamente jurídicos, uno de los de uso más flexible y contenido semántico mas variado, de ahí el interés de explorar su significado en contextos concretos, de observar la capacidad que contiene para articular argumentos opuestos que permiten su manipulación estratégica. Lo que sigue ha de entenderse como una aproximación en esta línea que ha de ser contrastado con muchos otros textos.

En la contestación a su hermano don Felipe, que había mandado decir que se despedía por desafueros quel rey fazía en la tierra, Alfonso $\mathrm{X}$ en su descargo, si podemos decirlo así, alude y admite los posibles desaguisados de sus oficiales, que ya había hecho enmendar. ¿Son éstos los actos que el infante consideraba desafueros? Para el rey desafueros son los que él ha cometido, haciendo un relato de los mismos : robar y tomar a los hidal gos y a los de las villas, a los monasterios y las órdenes todo lo que pudo; negarle a él el servicio debido por las mercedes y dineros concedidos, pactar con su peor enemigo, y en definitiva todas las acciones últimas en las que se le ha mostrado implicado ${ }^{44}$, porque

44. «Et lo que enbiastes dezir quel rey desaforaua Castilla e León, nunca lo él fizo nin fue su

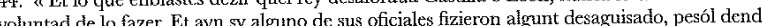
c estra de regnos de Castilla ed

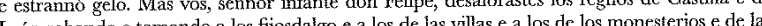
León robando e thiando a los hyosdalgo e a los de las villo Órdenes todo lo que vos podistes tomar, et demás faziéndouos el rey estas merçedes et estas honras e dándovos los dineros de las sus rentas e seyendo su vasalo, e tomándouos dél otra quantia grand de dineros de las sus rentas para le yr scruir do ćl mandase. Et enbiándovos dezi que avía menester vuestro seruiçio en la guerra de los moros e que fuésedes estar con el infante don Ferrando su fijo, non lo quesistes fazer. Lámavos agora quel vayades seruir los dineros que dél tomastes et la tierra que dél tenedes, e que enbiedes darí fiadores por las malfetrias que ches chich en la tira dicho non puede escusar de fazer contra vos lo que es fueno de Casill e leon. Lit mas vos enbía dezir quel dixicron que vos yuades al regno de Granada a ser en su ayuda, veyendo uo quel rey de Granada cs enemigo de Dios e de la fe e del rey e de los sus regnos e enemigo de quantos fijosdalgo ha en Castilla $\mathrm{e} \mathrm{cn}$ León $\mathrm{c}$ de todos los otros de sus regnos. E seyendo nos fijo del rey don Fernando et de la reyna donna Beatriz et hermano del rey don Alfonso, fazer esto tiene que deuiedes mejor guardar el linaje dondc venides e el debdo que con él avedes... " (p. 98) 
en todas estas cosas vos desforades la tierra e vos deseredades, e el rey no vos desafuera nin vos desereda.

También don Nuño había mandado despedirse del monarca porque desaforaua a Castilla e León y la respuesta regia, que va en el mismo sentido de devolver tal acusación, precisa más que en el mensaje anterior el contenido que para Alfonso X tiene el desafuero, contenido que es expresado en un tono de gran contundencia por el mensajero, aludiendo a los pedidos ilegales que este noble había exigido en la tierra que el rey le había dejado en encomienda, y en otros lugares y gentes, y a las tomas no autorizadas de conduchos y martiniegas. $\mathrm{E}$ l texto, dado el carácter de alocución directa es de gran expresividad y, ciertamente, merece ser reproducido:

Et a lo que vos dezides que desaforaua el rey a Castilla e a León, don Nunno, vos desaforastes al rey e desaforastes los sus fijosdalgo et los realengos e todos los abadengos echando uos pedido en toda la tierra en quanto la dexó en vaestra encomienda, estando él en la frontera. Et don Nunno, vos sabedes quel rey vos preguntó los pedidos que fezistes en su tierra si era fuero e vos dixiestes que non, mas que lo fizicran ante otros que vos e que por esto lo fiziérades vos. $\mathrm{E}$ dixouos el rey que pues non era fuero, que era fuerga e robo, et defendiónos que de allí adelante non fiziésedes aquellos desafueros et aquellas fuerças que auiades fecho. Et vos otorgastes gelo así que lo guardaríades. Et después sobre su defendimiento, estando el rey en Seuilla, echastes otro pedido en todos los fijosdalgo, caualleros et escuderos e duennas e donzellas en sus realengos et en sus ordenes, et tomaste conducho e cogistes sus martiniegas syn su mandado e sin sus cartas e fezísteslo coger muy desaguisadamente. $\mathrm{E}$ asi vos desaforaste la tierra (p. 101)

Es evidente que los referentes normativos invocados, tanto por el rey como por los nobles rebeldes, son los mismos, que las divergencias, corno antes advertimos, parecen tener que ver, más con coyunturas políticas de correlación de fuerzas diferentes que con opiniones teóricas contrarias respecto a un distinto código legal.

En la respuesta al de Haro, el rey, con argumentos parecidos, le atribuye a él el desafuero, que hace girar en torno a la honra, a los modos por los que

el rey ha honrado a muchos fijos dalgo... mas que otro rey que en Espanna fuese fasta en el su tiempo,

\section{y la deshonra que les ha producido don Lope}

porque feziste muchas cosas syn fuero, deshonrando los fijosdalgo e sus mugeres e sus fijos e stas parientes e otros muchos realengos... (p. 104),

deshonra y desafuero que también antes había asociado con los efectos de los tributos forzados achacados a don Nuño; desafuero es también no acudir a la guerra cuando el rey se lo había ordenado, habiendo recibido sus dineros, cometer malfetrías y, en definitiva, el gran alboroço de gentes armadas con el que se han alzado ${ }^{45}$.

Por todas estas cosas que avemos dicho, vos don Lope Díaz auedes desaforado al rey e a todos los fijos dalgo de Castilla e de León e a todos los realengos e abadengos, e lo que fazedes es contra fuero e contra derecho, e non podedes dezir que el rey vos desafuera, mas vos lo desaforades, que leuades los cauallos et las armas que conprastes de los sus dineros que vos él dio con que le siruiéscdes et vos ysle deseruir con ello (p. 105).

Es pues, éste del desafuero un motivo que han convertido en alegación común estos magnates para legitimar y concitar apoyo a su causa, por lo que todos ellos reciben del rey, aunque con palabras distintas, también una repuesta similar, como claramente se ve en el mensaje dirigido a don Fernando Ruiz de Castro que remite a los argumentos razonados previamente con los otros ricoshombres: dezimos que vos la desaforades, segúnt que auemos dicho a cada vno de los otros, resumiendo el mismo tipo de acusaciones que justifican la acción regia al respecto

Et si por todas estas cosas fiziera contra vos lo que es fuero de Castilla, entenderedes que es vuestra culpa (p. 106)

o a don Alvar Díaz a quien manda decir que

el desafuero et el tuerto de vos vino e de vos viene al rey e al regno, et ál non podedes dezir que de derecho sea (p. 110).

Se observa así que en este discurso el desheredamiento alegado por los rebeldes se convierte, en última instancia, en consecuencia - como pena legal por sus actos - del desafuero que ellos mismos, no el rey, han come-

45. «E demás, uos sabesdes que el rey estando en Murçia que vos enbió dezir de cómmo los moros fazían guerra, e que pues auíades tomado sus dineros, que vos mandaua e rogaua que fuésedes estar en aquella guerra con el infante don Ferrando, su fijo, e vos non lo quisiste fazer Et commo quicr que en esto le fuevtes desmandado enbínos rogar a rora e dezir que vayades Lt com qier que co csto le fuce estar en la frontera con el infante don Ferrando et que le siruades con la tierra e dineros que uos dél tomastes. E si esto non quisierades fazer, enbíauos el rey dezir que le vayades dar fiadores por las malfetrías que feziestes, para las entregar así commo es fuero. E si non, quel rey mandará entregar de los viestros bienes segunt çue es fuero de Castiella. Et otrosí uos sabedes que el rey vuestro sennor, veniendo a Burgos por uos sosegar en el su seruiçio, salistes a él ason[n] ando con muchas gentes de pie e de a cauallo armados commo nunca vinieron aquéllos onde vos venides a su rey e a su sennor natural. E uos e otros ricos omnes demandástele las cosas que quesistes et el rey otorgónoslas. Et sobre esto, a vuestro pedimiento, fizo ayuntar Cor-

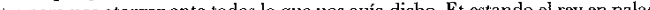

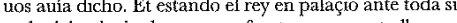
corte, fezźstele otras demandas $\mathrm{e}$ saliéstesle del palaçio do estaua e fuestes con grant alboroço de gentes armados sin le dezir ninguna cosa e robastes la tierra. Et agora fiziéronle entender que seyendo uos su vasallo e teniendo dél su tierra et sus dineros, que posistes pleito con el rey de Granada contra él. Et uos sabedes que el rey de Granada cs cnemigo de la fe e del rey e vuestro e de todos los fijosdalgo de Castiliza e de León, e querédesle descruir con tal omne commo éste que le ha mentido e falsado quantos pleitos puso con él e que quebrantadas las treguas, 》 (p. 104-105) 
tido. En definitiva, el rey en sus mensajes a los rebeldes deja muy claro lo que entiende por fuero y lo que es desafuero, y para ello no se inventa ni invoca un nuevo código, ni nuevas normas, sino que alude y remite a un viejo fuero, el de Ciastilla, supuestamente por ellos también invocado. Sin embargo, más que discutir aquí cuál puede ser, entre los conservados, el fuero aludido ${ }^{46}$, lo que nos interesa es llamar la atención sobre la apelación que se hace a un orden normativo bien conocido por todos, pues es precisamente la ruptura y no respeto del mismo lo que permite señalar la traición de estos ricoshombres, sin utilizar tal término ni llamanlos direc tamente traidores. De nuevo en este relato se representa al rey lleno de incredulidad, como si los vasallos a los que más ha beneficiado le traicionaran, de ahí los efectos retóricos de la detallada enumeración de mercedes y de la reiteración de los incumplimientos nobiliarios. Esta incredulidad, como ya advertimos, refiere de modo implícito a un código de valores y normas compartido. La noción de fuero en este contexto alude, por tanto, a un marco legal, pero también moral y político, en el que se definen los dos polos de la relación de intercambio, de reciprocidad política que caracterizaban las relaciones entre señor y vasallo: amor y merced por amor y servicio, como he señalado más arriba ${ }^{47}$. Desafuero viene a ser por ello una forma de reciprocidad negativa, derivada de la ruptura de los pactos de vasallaje, de las obligaciones mutuas que éste conlleva. Constituye en este caso y en términos generales el contenido de la rebelión, ese deseruir en muy mal son e en muy mala manera que el rey les reprocha ${ }^{48}$. Se podría pensar que el intento de Alfonso $\mathrm{X}$ es quebrar este bloque nobiliario que se le enfrenta, pero más parece un acto de propaganda

46. Pérez Prendes considera que los principios juridicos que inspirara estos alegatos de $\mathrm{Al}$ 46. Pére Pron también la columna vertebral del Espéculo, obra legislativa que ve como el « nervio fonso X so tancipal de la constitución politica » con la que este rey trataba de modificar « cl abu-

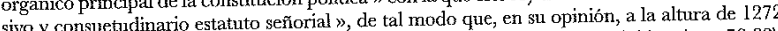
sivo y consuetudinario estatuto sinorifencenciadas : la del monarca y la señorial (op. cit., p. 76-82).

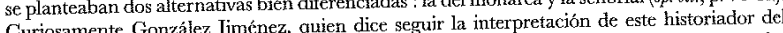
Ciriosamente Gon trataba

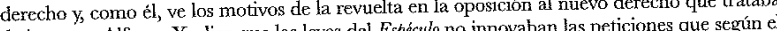
de imponer Alfonso X, dice que las leyes del Especulo no mnovaban las peticiones que segun el derecho tradicional podía hacer el rey (Crónica, p. 67, n. 107). La contradicción y error de esta referencia, no carecen de interés por cuanto muestran los problemas dc interpretación que suscitan los textos que comentamos, pero sobre todo nos advierten de las dificultades, que no precitan los textos que comentor haber resuelto aquí, para captar el contexto histórico en el que tuvieron significado. tendemos haber resuelto aquí, para captar el contexto fazer bien quando vos lo amásedes con 47. Las fórmulas son variadas: " auić sabor de uos fazer bien quándol... que les faría gran merçet » (p. 131). merçet $\gg$ (p. 131). expresión, para referirse a lo que en terminos actuales y para entender “ rebelión ", « revuelta» o « sublevacion ». Las expresiones usadas en la cronica hablan de «deservicio ", «alboroço", " tuerto e desaguisado", " yerro ", " ayuntamiento contra el rey», «enemistad», «desasosiego», « desavenencia », « dannos », «bolliçios e males" "guerra », «desafizero », « desfamar », « alçar e deseruir »... y sus opucstos explícitos. política que apela a unos parámetros de legitimidad compartidos para resquebrajar las razones del discurso rebelde.

$\mathrm{Y}$ es tal vez al detallar de nuevo lo ocurrido en el mensaje colectivo

a todos los infançones et caualleros fijosdalgo que sodes aquí et a los que non sodes aquí

donde más evidente aparece la deslegitimación del desaforado comportamiento nobiliario. Estrategias retóricas muy sutiles son aquí desplegadas. Dos aspectos importantes hay en esta presentación que potencian la autoridad del monarca : por un lado, los agravios y demandas que le habían hecho en Burgos se tornan ahora consejos, a los que había accedido porque eran pro de la tierra, forma de revestir una acción que podía entenderse como claudicación en otra buena y razonable ${ }^{49}$. Por otro, los deberes que estos nobles le deben se presentan de tal modo quebrantados, que esta conducta autoriza a que sus propios vasallos puedan romper el vasallaje pactado con ellos. Así, les manda decir, apelando al conocimiento que les supone de los hechos, pero también a la complicidad de sus implicaciones, con un vos sabedes, cómo

el rey les dio grandes tierras e buenas e muchos marauedís que diesen a vos para le servir con ellos, pero que en vez de este servicio lléuanlos a enemigos de Dios e de la fe e del rey,

haciendo referencia a las alianzas que han establecido con el rey de Granada. De este modo, continua el mensajero regio,

con aquel aver mesmo que el rey uos mandó dar con quel seruiésedes, con aquello vos lieuan a do lo desiruades syn Dios et syn razon,

y apelando a la memoria de la fidelidad de sus padres

que siempre cataron lealtad e derecho en fueros et en otras cosas quel pidie-

ron,

les aclara que no están obligados a seguir a tales señores, forma ésta no tanto de eximirles de responsabilidad como de apelar a la que les corresponde respecto a su señor natural que es del que proceden los dineros que han recibido :

dezimos que non deuedes de yr con ellos contra vuestro sennor natural, ca

49. « $\mathrm{Ca}$, si fuero demandaron, dieron gelo e otorgaron gelo por su palabra en corte e por preuillejio. Et otras cosas quel dixicron quel consejauan que era pro de la tierra quisolas é fazer así commo ellos et los ricos omnes de Castilla e de León gelo consejaron... 》 (p. 111 ). Estrategia similar a la que luego va a utilizar en el ayuntamiento de Almagro, donde cambia el carácte des dmandas rebeles y lon conirte en concesiones revias del reino, forma de atribuirse en ese momento el éxito del resultado negociador, es decir, de la avenencia conseguida (cap. XLVII). 
aquello que ellos vos dieron porgue sodes sus vasallos, el rey gelo dio de lo suyo e non vos lo dieron ellos de sus heredades. Et si algo non vos diesen, non seríades sus vasallos nin yríades con ellos por parentesco nin por debdo que con ellos ayades. Et pues la razón del vasallaje que an de vos es por los dineros que vos dieron de los quel rey les dio a ellos, et por estos dineros avedes a fazer serviçio e a mí avedes de seruir donde viene $\mathrm{el}$ auer que vos fue dado, mayormente a vuestro sennor natural (p. 11).

Este modo de deslegitimar la revuelta de la alta nobleza por parte del rey, delante precisamente de aquellos que la nutren, reitera la exigencia del cumplimiento de obligaciones recíprocas, que no se limitan como pudiera parecer a primera vista a los intercambios de dineros por servicios, y viceversa, sino que afectan al comportamiento adecuado en el interior de estos grupos sociales según un conjunto de regulaciones normativas y valores culturales que son - insistimos en esto - morales y políticos al mismo tiempo. De la adecuación a los mismos dependerán, por tanto, esos bienes intangibles y contingentes que constituyen la reputación y prestigio, la honra y el honor personales, que es dado otorgar a la comunidad tanto divina como humana, tal como advierte el rey en su mensaje a estos caballeros:

Porque vos dezimos que catedes lealtad e derecho e fuero e lo que deuedes de

fazer porque Dios nin los ommes non ayan qué dezir (p. 111).

Este orden moral-normativo que se invoca, dada la clara hegemonía que adquiere el principio de reciprocidad, eje por el que se miden y juzgan comportamientos, y no sólo en las cortes de justicia sino también, como vemos, en el terreno de la pública fama, extendida asimismo al ámbito divino ${ }^{50}$, aparece así como un « orden natural » más que ideológico $^{51}$.

Merece destacarse que en este debate político - tal como nos es presentado en este proceso de lucha y negociación - el fuero caballeresco que es utilizado para articular las demandas contrapuestas de las dos partes en conflicto sale, por ello, fortalecido, porque el rey no discute que la actuación nobiliaria pudiera haber estado justificada, si realmente él hubiese hecho los actos que se le imputan : tomarles tierra o desheredar-

50. El control social cjercido a través de la reputación y fama públicas aparece en diversos 50. El con aludir a su «loco" contextos, el ternino s comportamiento con los reyes (p. 148), o a los caballen que ron se saben «malandantes » (p. 149), son la clara y opuesta expresión del buen cabailero andante. Es más, el prestigio del rey igualmente se construye de este modo, es decir, puede verse afectado por lo que se diga de sus acciones.

51. Sobre este proceso de la naturalización ideológica, adenás del trabajo clásico de P. BOURDIEU EI sentido práctico, puede verse una valiosa reformulación en John COMAROFF y Jean COMAROFF, Ethnography and the historical imagination, Oxford, 1992, p. 27-29. les sin razón, sin merecerlo... Pero no lo ha realizado, y es esta contraposición entre ambos comportamientos, eje de articulación de los mensajes regios comentados, la que utiliza de nuevo para desvelar a su hijo Fernando las razones ocultas que animan el movimiento nobiliario :

Estos ricos omes non se mouieron contra mi por razón de fuero nin por tuerto que les yo touiese, ca fuero nunca gelo yo tollí, Más, que gelo touiese tollido, pues que gelo otorgaua, mas pagados deuieran ser et quedar deuieran contentos. Otrosi tuerto nunca gelo fiz. Mas que gelo ouiese fecho el mayor del mundo, pues que gelo quería emendar a su bien vista dellos, non auién por qué más demandar. Otrosí por pro de la tierra non lo fazen, ca esto non lo querian tanto ninguno commo yo, cuya es la heredat, e muy poca pro han ellos ende sy non el bien que les nos fazemos. Mas la razón porque lo fezieron fue ésta : porque querian tener syempre los reyes apremiados e leuar dellos lo suyo pesándoles e buscando carreras por do los deseredasen e los desonrasen, commo lo buscaron aquéllos donde ellos vienen. Et asy commo los reyes criaron a ellos, punaron ellos de los descriar e de tollerles los reynos, algunos dellos seyendo ninnos. $\mathrm{E}$ asy commo los reyes los heredaron, punaron ellos de los desheredar lo vno consejeramente con sus enemigos, lo ál a furto en la tierra, leuándoles lo suyo, poco a poco anagenándogelo. Et asy commo los reyes les apoderaron e los onraron, ellos punaron en los desapoderar e los desonrar en tantas maneras que serían muchas de contar e muy vergonnosas... (cap. 52)

Advertencias cargadas de amarga ironía con las que quiere hacer entender a su hijo que

esto es el fuero e pro de la tierra que ellos syempre quisieron ${ }^{52}$.

No es pues el derecho lo que se discute, sino los hechos, y esto por referencia a fueros antiguos - que supuestamente Alfonso X habría abolido. Y lo mismo cabe decir de los rebeldes, o mejor de los nobles desavenidos como así mismos se denominan, que en la respuesta colectiva asumen explícitamente los términos de intercambio invocados por el rey, las obligaciones forales podríamos decir, pero manipulando estratégicamente su contenido:

[...] a lo que dezides que pues el rey nos dio su tierra e sus marauedís que le deuemos seruir, dezides derecho e nos le enbiamos dezir que sy quiere nuestro

52. Este texto, de tanta riqueza informativa como belleza literaria, se ha considerado igualmente una transcripción literal hecha por el cronista de un diploma real. Sin embargo, me permito nuevamente disentir de esta interpretación, al menos - a falta de pruchas -, cuestionarla, pues pienso que no deberiamos descartar la posibilidad de que fuera otro de los sofisticados recursos retóricos salidos de la propia pluma del canciller de Alfonso XI. i Acaso, no se condenre tos del mismo carácter didáctico-consiliar? A pesar de que Fernando Gómez Redondo es de la primera opinión, en su libro - magistral por tantos conceptos - se pueden encontrar los datos que avalan mis argumentos. Sobre la carta, p. 972, n. 205. 
seruiçio, que le seruiremos. Mas agora demándanoslo en tiempo que to non podemos fazer,

de lo que se contradicen, o burlan, en el final de la respuesta :

[...] pues con él non beuimos nin su merçet non avemos, non podemos escusar que non vayamos buscar do biuamos (p. 112).

Aunque no es nuestra intención extender el análisis a todo el material de la crónica, es preciso retener este uso estratégico de recursos comunes, de una común cultura jurídica, que se advierte igualmente en todo el discurso regio, pero de modo muy evidente en ese último mensaje a todos los caballeros al que nos hemos referido, pues al darles razones para romper con sus señores, elimina la intermediación nobiliaria y afirma la primacía del vínculo de naturaleza - un vínculo en el debdo y natura aparecen estrechamente imbricados - sobre el que pretende basar su autoridad ${ }^{53}$. El fuero y el derecho sirven así, tal como aparecen en este relato, como metáfora de la reciprocidad política que se exigen mutuamente, como noción que permite abarcar los derechos de unos y otros, manteniendo su jerarquía, tal como se manifiesta en la avenencia final cuando el rey al otorgarles, por ruego de la reina y de su hijo,

los fueros e vsos e costumbres que ouieron en tiempo de los reyes de Castilla e de León,

asume igual contrapartida

guardando ellos al rey su sennorío e sus fueros e sus derechos (p. 159).

¿Estamos, por tanto, - podemos preguntarnos - ante la manifestación de un modelo regalista de carácter aristocrático, en el que la nobleza comparte con el rey el gobierno del reino y que, tal como se dice, Alfonso $\mathrm{X}$ se ve obligado a concretar en su Segunda partida ${ }^{54}$ ? Ciertamente,

53. Sin duda, no es este el lugar para tratar los múltiples problemas que plantea esta noción. Es un tema todavia insuficientemente estudiado, sobre el que pienso es necesario volver. $\mathrm{Me}$ cilas de la Cuarta partida que considero relacionadas "Naturaleza tanto him. anc a inchir dos chlo quiere dezir cono debdo que han los on se amar e en se querer bien. E el departimiento que ha cntre natura e naturaleza es éste. Ca natura es una virtud que faze ser todas las cosas en aquel estado que Dios las ordenó. Naturaleza es cosa que semeja a la natura e que ayuda a ser e mantener en todo lo que desciende d'ella » $[P \Gamma V, \mathrm{xxv}, 60]$; « Desnaturar segund lenguaje de España tanto quicre dezir como salir ome de la naturaleza que ha con su señor, o con la tierra en que bive. E porque esto es como debda de natura, non se puede desatar, si non por alguna derecha razó. " $[P \Gamma V, \mathrm{xxV}, 61]$

54. Así parece interpretarlo Fernando Gómez Redondo, que ve en esa Partido plasmado el 51. A parce in model cabale crónica (Kistoria de la prosa, p. 536-569). Opinion discutida recientemente por Georges Martin para quien, por el contrario, dicha Partida representa el modelo regio para someter a la nobleza : « Violencia, autoridad, consenso. La caballería según Alfonso X el Sajio » in : Lucha poltica : condena y legitimación en las sociedades mediezales (en prensa). Esta discusión enlaza con la hay que admitir que la mayor fuerza de la imagen del rey de esta crónica, del discurso político vertido en sus mensajes, reside precisamente en las acusaciones y reproches que hace a los ricoshombres rebeldes de estar violando con sus acciones el propio código caballeresco y sus propias normas de convivencia, esas reglas del juego político - si utilizamos una expresión que ha devenido común ${ }^{55}$ - que según se nos ha dicho eran las que estos nobles estaban intentando defender frente a proyectos más regalistas de Alfonso el Sabio. recogida en n. 47. Para un análisis del modelo regio propiesto en el Espectio en contraposición con el que se disefia en la Segunda partida ver F. GOMEZ REDONDO, op. ait., p. 354-357, 516 519 y $547-570$.

55. Es el título del libro de Gerd ALTHOFF, Spielregeln der Politik im Mittelalter : Komunikation in Frieden und Fehde, Darmstadt : Primus, 1997. 